\title{
ARGENTINA Y ESPAÑA: REPRESENTACIONES DE LA JUVENTUD Y LA CULTURA FÍSICA ARGENTINAS EN IMÁGENES DEL NO-DO ESPAÑOL
}

\author{
Argentina and Spain: Argentinean youth and Physical Culture \\ representations in No-Do images
}

\section{Eduardo Lautaro Galak ${ }^{\alpha}$}

Fecha de recepción: 03/07/2020 • Fecha de aceptación: 18/09/2020

Resumen. El objetivo es analizar los usos del cine informativo documental como artefacto cultural capaz de ser utilizado como dispositivo pedagógico. Para ello se estudian diversas imágenes en movimiento filmadas en Argentina que fueron proyectadas en España en el segundo cuarto del siglo XX con la intención de comprender cómo se conforma una estética simétrica para narrar prácticas corporales de y para la juventud.

El cine documental informativo, especialmente el género noticieros cinematográficos, consistió en un recurso para la proyección masiva de comunicaciones en forma de noticias nacionales e internacionales. Se observa una familiaridad en las imágenes analizadas que produjeron el principal noticiero cinematográfico argentino entre 1938-1955, Sucesos Argentinos, con otros realizados en el segundo cuarto del siglo XX en España, a través del No-Do. Más allá de la influencia económica, política y cultural, Argentina exportó a España modos de narrar prácticas corporales organizadas estatalmente. Amparados en retóricas nacionalistas características del período entreguerras y durante la Segunda Guerra Mundial, puede afirmarse que existió una estética transnacional de cómo narrar las técnicas corporales y culturales correctas. A través de imágenes que en estos países se proyectaban obligatoriamente en todas las salas, los noticieros cinematográficos transmitieron simultánea y homogéneamente un discurso -todo, a todos, al mismo tiempo-, resultando una verdadera pedagogía transnacional. En síntesis, se estudia una

\footnotetext{
${ }^{\alpha}$ IDIHCS. Instituto de Investigaciones en Humanidades y Ciencias Sociales - Universidad Nacional de La Plata-CONICET. Calle 51 e/ 124 y 125.- 1925- Ensenada, Provincia de Buenos Aires, Argentina. egalak@fahce.unlp.edu.ar (D) https://orcid.org/0000-0002-0684-121X
} 
pedagogía por fuera de los muros escolares a través de imágenes de cine documental informativo del segundo cuarto del siglo XX que tienen por objeto la formación de los cuerpos y de las sensibilidades.

Palabras claves: noticiero cinematográfico; juventud; cultura física; Argentina; España.

Abstract. The aim of this article is to analyze the uses of documentary informative cinema as a cultural artifact which was employed as a pedagogical device. To do so, we studied motion pictures filmed in Argentina and shown in Spain in the second quarter of the 20th century, in an attempt to understand how a symmetrical aesthetic is shaped to narrate the bodily practices of youth.

Informative documentary cinema, especially newsreels, constituted a resource for mass communications. A familiarity can be observed between the Argentinean images analyzed between 1938-1955 in Sucesos Argentinos, with others made in the second quarter of the 20th century in Spain, through No-Do. In addition to economic, political and cultural influences, Argentina imported into Spain ways of narrating state-organized physical culture. Sheltered in a nationalist rhetoric characteristic of the interwar period and the Second World War, it can be affirmed that there was a transnational aesthetic of how to narrate correct corporal and cultural comportment. Through images that were projected in theaters in these countries, newsreel broadcasts simultaneously and homogeneously transmitted the same discourse-everything, to everyone, at the same time-, resulting in a true transnational pedagogy. In short, a pedagogy outside the school walls is studied through informative documentary film images from the second quarter of the 20th century that aimed to form bodies and sensibilities.

Keywords: newsreel; youth; physical culture; Argentina; Spain.

\section{INTRODUCCIÓN}

Las relaciones entre Argentina y España pueden datarse desde la fundación de la primera a partir de una separación de dependencia política y comercial de la segunda, en el proceso que ocurre en los inicios del siglo XIX. Si bien estos antecedentes, no es sobre esta historia general que esta investigación aborda, sino sobre otra particular, que también presenta una relativa mutua dependencia: la proyección de fotogramas argentinos en los orígenes del cine documental informativo semanal español. En efecto, en los inicios de los noticieros cinematográficos oficiales españoles se mostraron imágenes producidas en Argentina para 
narrar la realidad nacional política, cultural, social, religiosa, militar, comercial, deportiva y educativa. La intención es, precisamente, relevar y analizar los micros fílmicos referidos a lo pedagógico y a lo escolar en el principal formato de prensa cinematográfica española: el No-Do.

Esta indagación se enmarca en un proyecto de investigación más amplio cuya hipótesis es que los noticieros cinematográficos funcionaron como dispositivos pedagógicos en la mayoría de los países occidentales, desplegando una educación (con) la mirada. Ello implica que, por un lado, las imágenes exhiben modos correctos de hacer, pensar y decir para que sean aprendidos. En otras palabras, resignificando el sentido que desarrolla Walter Benjamin contemporáneamente a estas imágenes, ${ }^{1}$ la reproductibilidad técnica de las artes mecánicas, como el cine, habilita a una reproductibilidad técnica que lo torna un recurso político de masificación de un mismo ideario. Como en una suerte de reinterpretación del legado pedagógico de Comenio en su Didáctica Magna, el cine informativo documental semanal permite, por fuera de los muros escolares, la transmisión simultánea y homogénea de un mismo discurso: todo, a todos, al mismo tiempo. Por el otro, la proyección de las imágenes en movimiento en forma de prensa cinematográfica tiene como objetivo implícito educar mediante ese mismo gesto de mostración: hay claramente una intencionalidad pedagógica que se propone no solo la transmisión de modos correctos de hacer, sino también de modos correctos de ser. Una educación de la mirada, de las maneras en las que percibimos el mundo, las cosas y las palabras. En términos de Jacques Rancière, el cine proyectado masivamente funciona como una técnica para la reproducción de modos de ser sensibles, que hacen que se desarrolle una estética simétrica universalizada percibida como particular. ${ }^{2}$ De esta dialéctica histórica entre educar la mirada y educar con la mirada se pretende aprehender genealógicamente discursos que condicionan prácticas actuales.

\footnotetext{
1 Walter Benjamin, La obra de arte en la era de su reproductibilidad técnica y otros textos (Buenos Aires: Godot, 2012).

2 Jacques Rancière, Las distancias del cine (Buenos Aires: Manantial, 2012) y El reparto de lo sensible: estética y política (Buenos Aires: Prometeo, 2014). Esta tesis puede ser profundizada con la lectura de Eduardo Galak, «Educar (con) la mirada. Discursos políticos y sentidos estéticos sobre la cultura física en noticieros cinematográficos», en Gregorio Weinberg: escritos en su honor, ed. Gabriela Ossenbach Sauter (Buenos Aires: CLACSO, 2017), 55-74.
} 
El proyecto de investigación mencionado al principio abarca el período de producciones fílmicas entre 1938 y 1955, siendo el año de inicio cuando comenzaron a proyectarse los Sucesos Argentinos, el noticiero cinematográfico más importante de la historia argentina, y cerrándose con el derrocamiento de Juan Domingo Perón. Los Sucesos Argentinos fueron una empresa fílmica informativa comercial privada, creada bajo la dirección de Antonio Ángel Díaz, que se estrenaron el 26 de agosto de 1938 y que tuvieron pantalla hasta 1972, previa reconversión en una cooperativa por no poder competir con otros medios de comunicación, especialmente con la televisión. Si bien se autodenominaban como el «Primer semanario cinematográfico latinoamericano», no fue el primero en Latinoamérica, y ni siquiera en Argentina, que tuvo experiencias previas con las Actualidades Argentinas de Max Glücksmann en la década de 1910 y el Film Revista Valle en la década de 1920, entre otras. ${ }^{3}$ Más allá de eso, los Sucesos Argentinos fueron el más representativo de todos los formatos de prensa cinematográfica en la Argentina debido a que perduraron más tiempo en pantalla, a su significatividad cultural que trascendió generaciones y a los fuertes vínculos políticos que tejió en el tercio de siglo en el funcionó. ${ }^{4}$

Como explica María Florencia Luchetti, ${ }^{5}$ apenas 5 años después de haber nacido la productora de Antonio Ángel Díaz, en 1943, y en plena presidencia de Pedro Pablo Ramírez, se promulgó el Decreto 18.405 (publicado el 13 de enero de 1944) en el cual se establece que sea obligatorio proyectar en todo el territorio argentino noticiarios producidos localmente «cuyo contenido, a juicio de la Subsecretaría de Informaciones y Prensa, sea considerando de propaganda nacional», y con el objeto de «llevar a todos los ámbitos una impresión objetiva y completa de la vida nacional».6 Se

\footnotetext{
${ }^{3}$ Para profundizar sobre los inicios de la prensa cinematográfica argentina se recomienda la lectura de Irene Marrone, Imágenes del mundo histórico. Identidades y representaciones en el noticiero y el documental en el cine mudo argentino (Buenos Aires: Biblos, 2003) y de María Florencia Luchetti, «El noticiario cinematográfico en Argentina. Un estado de la cuestión». Aniki, 3, nº 2 (2016): 303-333.

${ }^{4}$ Clara Kriger. «El noticiero Sucesos Argentinos». Historiapolítica.com, 2007. http://historiapolitica. com/datos/biblioteca/kriger.pdf. (consultado el 23/01/2020).

${ }_{5}^{5}$ María Florencia Luchetti, «¿Qué sucedió en la semana, eh? El noticiario cinematográfico en Argentina. Aportes para la construcción de un objeto» (Tesis de Maestría, Universidad de Buenos Aires, 2011).

${ }^{6}$ Es importante señalar que este Decreto de 1943 es relativamente contemporáneo a lo que ocurría en otros países, ya que, según Paulo Antonio Paranaguá, los noticieros cinematográficos son de
} 
reguló, además, que los noticieros debían tener una duración mínima de 8 minutos, y ser exhibidos antes de los largometrajes en las salas de cines de todo el país, como «vehículo de propaganda nacional tendiendo a una más íntima compenetración entre gobernantes y pueblo».7 En este mismo Decreto se le otorga el 70\% de las salas cinematográficas a los Sucesos Argentinos, lo cual demuestra que hacia 1944 la empresa privada de Antonio Ángel Díaz ya ocupaba oficialmente la mayoría del espacio de la prensa cinematográfica argentina.

Con la llegada a la Presidencia argentina de Juan Domingo Perón, los noticieros cinematográficos se resignificaron, tornándose claramente un recurso comunicativo política y estética, configurándose como un dispositivo de propaganda peronista. ${ }^{8}$ El golpe de Estado a manos de una dictadura cívico-militar autoproclamada como Revolución Libertadora en 1955 interrumpe este proceso, menoscabando el desarrollo de un mecanismo de fuerte incentivo oficial a la producción local de noticias filmadas, desinvirtiendo en el fomento a su exhibición obligatoria en todas las salas del país y provocando la merma de la salida al cine como fenómeno no solamente masivo, sino también popular. ${ }^{9}$

Teniendo en cuenta este telón de fondo, esta investigación en particular retoma ese recorte temporal sobre imágenes argentinas y se propone pensarlo específicamente para el cine documental informativo español. Partiendo de reconocer que en España existieron diferentes empresas públicas regionales y privadas sobre cine documental informativo, ${ }^{10}$ ninguna ocupa una relevancia social como el No-Do, un

exhibición obligatoria en Brasil desde 1932, en Colombia desde 1942 y en Perú desde 1944. Paulo Antonio Paranaguá, El cine documental en América Latina (Madrid: Cátedra, 2003).

7 Argentina. «Fomento a la producción de noticiarios en Argentina». Boletín Oficial de la República Argentina, Decreto Nacional n 18.405, publicado el 13 de enero de 1944.

8 Eduardo Galak, «Hacia una estética peronista: educación del cuerpo y formación de subjetividades a través del noticiero cinematográfico "Sucesos Argentinos" (1946-1955)», en La educación de las sensibilidades en la Argentina moderna. Estudios sobre estética escolar, eds. Pablo Pineau, María Silvia Serra y Myriam Southwell (Buenos Aires: Biblos, 2018), 211-225.

9 Clara Kriger. Cine y peronismo: el Estado en escena (Buenos Aires: Siglo XXI, 2009).

${ }^{10}$ Para ver un estudio sobre las producciones fílmicas documentales españolas sobre educación anteriores a 1943, se recomienda la lectura de Eulàlia Collelldemont Pujadas y Josep Casanovas Prat, "Los documentales y noticiarios como texto de apertura para pensar la educación estético-política», Historia y Memoria de la Educación, 5 (2017): 467-487 y Nuria Álvarez Macías, «Cine y educación en la España de las primeras décadas del siglo XX. Tres concepciones del cine educativo», Tarbiya, 
emprendimiento estatal que funcionó como artefacto cultural de propaganda oficial del gobierno de Francisco Franco (Tranche y Sánchez-Biosca, 2006). Acrónimo de Noticiarios y Documentales, el No-Do comenzó a funcionar formalmente en 1943, aunque sus antecedentes directos se inician el 22 de diciembre de 1942, gracias al decreto que reglamenta como obligatorio y de responsabilidad estatal la proyección de noticias filmadas (España, 1942).

Con esto, el primer objetivo de esta investigación es rastrear y analizar aquellas imágenes argentinas sobre educación exhibidas en el cine informativo documental entre 1943 y 1955 en España, a través del NoDo. Antes de continuar, cabe realizar dos aclaraciones introductorias. Primero, que en rigor de verdad los Noticiarios y Documentales españoles tienen desde su origen una relación con un organismo oficial educativo: el mencionado decreto de 1942 establece que los No-Do pertenezcan a un departamento de la Dirección de Cinematografía y Teatro, dependiente de la Vicesecretaría de Educación popular, dentro del Ministerio de Educación Nacional. Inclusive, apenas tres años más tarde, el 4 de marzo de 1946, se establece una regulación jurídico-económica, en la que se decreta que «el patrimonio de toda clase, de Noticiarios y Documentales Cinematográficos (NO-DO), ya se refiera a inmuebles, mobiliario, elementos de producción, maquinaria, películas producidas, se entenderá siempre propiedad del Estado y adscrito al servicio del Ministerio de Educación Nacional». ${ }^{11}$ Segundo, que si bien se concibe como tesis que toda la cinematografía informativa documental tiene en el fondo un carácter de dispositivo pedagógico, a los fines de esta investigación se tomarán aquellas imágenes que explícitamente se reconozcan como parte de los procesos de escolarización: esto es, sean dentro o fuera de los muros escolares, pero que funcionen performativamente como pedagógicas, con objetivos claros y manifiestos de transmitir un mensaje correcto.

revista de Investigación e Innovación Educativa, 31 (2002): 39-66. En tanto que para observar específicamente lo corporal, véase Eulàlia Collelldemont Pujadas, Núria Padrós-Tuneu y Pilar Prat Viñolas, «El registro de documentales y noticiarios, una oportunidad para incrementar la documentación del patrimonio histórico educativo", Revista Iberoamericana Patrimonio HistóricoEducativo, 5 (2019): 1-18.

11 «Decreto de 22 de febrero de 1946 por el que se regula el régimen jurídico-económico de Noticiarios y Documentales Cinematográficos (NO-DO)», Boletín Oficial del Estado (España) (04/03/1946b): 1697-1698. 


\section{IMÁGENES E IMAGINARIOS ARGENTINOS EN ESPAÑA}

Antes del surgimiento del No-Do, se promulgó en 1942 un acuerdo comercial entre Argentina y España, en el que se propone con «urgencia de promover una íntima colaboración cultural entre España y Argentina, con el propósito de fortalecer la defensa y jerarquía de los inmutables valores del espíritu que le son comunes y que forman la base más sólida de sus respectivas nacionalidades». ${ }^{12}$ En este contexto, la industria cinematográfica de ambas naciones comienza a desarrollar relaciones económicas, comerciales y artísticas. Entre otras, se destacan los intentos de Antonio Ángel Díaz y del gobierno argentino desde 1941 para proyectar los Sucesos Argentinos en España, como «producto fundamental con vistas a mejorar el mutuo conocimiento y afianzar los lazos de amistad»,13 cuestión que naufraga en vaivenes hasta la aparición del No-Do.

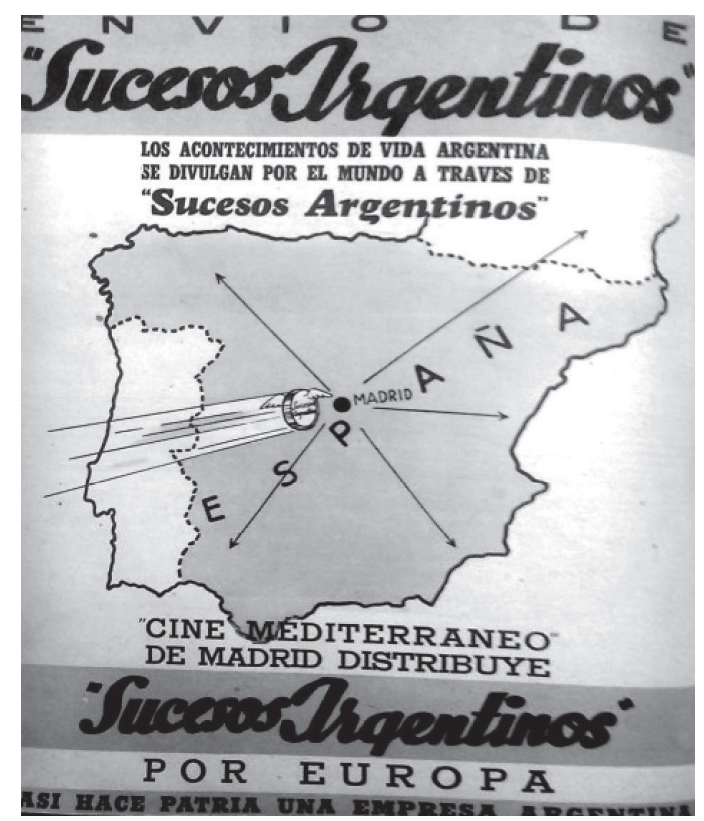

Imagen 1. Publicidad en Cine Argentino - 19 de febrero de 1942 [fuente: Díez Puertas, 2019: 141].

\footnotetext{
12 Emeterio Díez Puertas, «Las negociaciones para el acuerdo cinematográfico de 1948 entre Argentina y España (1939-1948)». Secuencias 35. (2012): 59-83.

13 Emeterio Díez Puertas, Cine español y geopolítica fascista: España y sus relaciones cinematográficas con la Argentina (1939-1943) (Madrid: Síntesis, 2019), 140.
} 
Esta publicidad ilustra el clima de época en 1942 respecto de la intención de fondo de la relación entre Argentina y España que se procuraba establecer por aquellos años: que Madrid funcione como nodo para la retransmisión de noticias argentinas en toda Europa. No es menor el hecho de que esto haya sido publicado en una de las revistas cinéfilas de habla hispana históricamente más importantes como fue Cine Argentino, cuyo editor fue el propio Antonio Ángel Díaz, creada unos meses antes de que funde los Sucesos Argentinos. Inclusive, según se explicitaba en esta publicación, "Sucesos Argentinos es un noticiario de nuestra revista ampliando su función periodística» ${ }^{14}$, por lo que puede pensarse que es un desprendimiento audiovisual de una empresa gráfica.

A la salida de la Segunda Guerra Mundial y frente al proteccionismo que se vivía a ambos márgenes del Atlántico, ${ }^{15}$ se desarrollan entre 1946 y 1948 pactos comerciales de empresas y contenidos fílmicos con mayor profundidad. ${ }^{16}$ Si entre 1939 y 1947 Argentina vendió un promedio de 9 películas por año a España, lo cual representaba el 5\% de las importaciones hispánicas, a partir de los acuerdos de 1948 se buscaría alcanzar

\footnotetext{
14 Cine Argentino, «Sucesos Argentinos. Un exponente del periodismo», Director Propietario Antonio Ángel Díaz, n. ${ }^{\circ} 17,01 / 09 / 1938$.

${ }^{15}$ Herencia de una fuerte intervención de los Aliados -especialmente de Estados Unidos- para gobernar los contenidos y su comercialización transnacional a través de subsidios y de regulación del celuloide para la filmación, los últimos años de la Segunda Guerra Mundial y la posguerra muestra la fuerte dependencia del mercado cinematográfico local al contexto geopolítico, tanto para la producción como para la distribución de las imágenes. Al respecto pueden verse Clara Kriger, «La presencia del estado en el cine del primer peronismo» (Tesis doctoral, Universidad de Buenos Aires, 2006) y Emeterio Díez Puertas, «Las negociaciones para el acuerdo cinematográfico de 1948 entre Argentina y España (1939-1948)». Secuencias 35. (2012): 59-83. En otras palabras, los vínculos cinematográficos transnacionales tienen una clara dependencia de las relaciones internacionales políticas estatales, inclusive para los emprendimientos comerciales privados. Por caso, el Certamen Cinematográfico Hispanoamericano, organizado en 1948, fungió como plataforma para cierta normalización de las relaciones cinéfilas entre España y México que habían sido cortadas por el conflicto armado, y con esto se produjo en los siguientes años acuerdos comerciales de intercambio que profundizaron la disputa latina por el mercado fílmico entre Argentina y México. En otras palabras, las relaciones cinematográficas entre España con estos dos países latinoamericanos se pueden explicar por la inmediata afinidad del franquismo con el peronismo y el tardío reconocimiento mexicano al gobierno de Franco. Véase Josefina Martínez, «La incidencia de la Segunda Guerra Mundial en el comercio de películas entre España y Argentina. La búsqueda de un acuerdo imposible», Bicentenario. Revista de Historia de Chile y América 7 (2008).
}

16 Josefina Martínez, «La incidencia de la Segunda Guerra Mundial en el comercio de películas entre España y Argentina. La búsqueda de un acuerdo imposible», Bicentenario. Revista de Historia de Chile y América 7 (2008) y Clara Kriger, Cine y peronismo: el Estado en escena (Buenos Aires: Siglo XXI, 2009). 
el 15\% con una cuota de 25 películas anuales. ${ }^{17}$ Emeterio Díez Puertas afirma que, según las estadísticas del Sindicato Nacional del Espectáculo, entre 1939 y 1954 Argentina es el séptimo país suministrador de largometrajes para el mercado español, representando un $6 \%$ del total, apenas por detrás de imponentes mercados de industrias cinematográficas como los de Estados Unidos, México, Gran Bretaña, Italia, Francia y Alemania. ${ }^{18}$ Durante los años de Perón como presidente argentino (19461955), y gracias a convenios específicos, las películas argentinas y españolas alcanzarían una cuota de 7\% del mercado del otro país, duplicando el período anterior, algo que benefició especialmente a España. ${ }^{19}$

La presencia de imágenes internacionales en el cine español también es manifiesta en lo que respecta a la prensa filmada. Si bien según Mercedes Rodríguez Sánchez ${ }^{20}$ el No-Do se formó en un noventa por ciento sobre la base de Actualidades UFA, el noticiario de Universum Film AG, el estudio cinematográfico alemán más importante de la época, es posible ver recurrentemente imágenes sobre Argentina, inclusive desde su primera edición. El intercambio de películas documentales informativas con el extranjero permitió un doble juego: por un lado, conseguir material fílmico para utilizar en su sección internacional del No-Do y, por el otro, mediante la reciprocidad con noticieros de otros países, ejercer un control de forma relativamente directa sobre las informaciones y opiniones sobre España que se proyectaban fuera de territorio ibérico.

Según Rafael Tranche y Vicente Sánchez-Biosca, ${ }^{21}$ entre 1943 y 1961 España exportó más de un millón de metros de celuloide de No-Do. Los suministradores de prensa filmada internacional para los Noticiarios y

\footnotetext{
${ }^{17}$ El principal acuerdo es el denominado Protocolo Franco-Perón, firmado el 9 de abril de 1948, que salvó a la dictadura franquista. Para profundizar puede leerse Raanan Rein, La salvación de una dictadura. Alianza Franco-Perón, 1946-1955 (Madrid: Consejo Superior de Investigaciones Científicas, 1995).

18 Díez Puertas, "Las negociaciones para el acuerdo cinematográfico de 1948 entre Argentina y España (1939-1948)».

19 Josefina Martínez. «La intimidad latina. El intercambio de películas entre Argentina y España durante el primer gobierno de Perón (1946-1955)». Bicentenario. Revista de Historia de Chile y América 8, n. ${ }^{\circ} 2$ (2009): 63-96.

${ }_{20}$ Mercedes Rodríguez Sánchez, «La Segunda Guerra Mundial en el NO-DO (1943-1945)» (Tesis doctoral, Universidad Complutense de Madrid, 2016), 656.

${ }^{21}$ Vicente Sánchez-Biosca, "La hispanidad en la pantalla del No-Do», en Cine documental en América latina, ed. Paulo Antonio Paranaguá (Madrid: Ediciones Cátedra, 2003), 109-122.
} 
Documentales durante la Segunda Guerra Mundial fueron Estados Unidos, Alemania y Gran Bretaña, y secundariamente Francia, Italia y Japón. ${ }^{22}$ A este listado de países cabe sumar a las noticias argentinas: en las 90 ediciones $^{23}$ No-Do de 1943 hubo 17 noticias argentinas, lo cual representa que en un $18,88 \%$ de las transmisiones se proyectaron micros fílmicos de y sobre Argentina. En tanto en 1944 hubo 102 ediciones, con 7 noticias sobre Argentina, un 6,86\% del total. La notoria baja en imágenes argentinas en España en 1945, con solo una presencia acerca de la entrega de credenciales del embajador a Franco (n. ${ }^{\circ}$ 129B), puede explicarse por las vicisitudes internacionales del fin de la Segunda Guerra Mundial.

Panorama que se modifica notoriamente en 1946, no sólo por la resolución del conflicto bélico, sino principalmente por una decisión política de la dictadura franquista. La decisión tomada de que a partir del 25 de enero de 1946 se exima del pago de derechos arancelarios para la importación de noticieros extranjeros a España que sean destinados al No-Do (España, 1946a) explica por qué, si en los primeros tres años, en el lapso entre 1943 y 1945, aparecieron 25 noticias sobre Argentina, en el siguiente trienio ese número se ampliaría exponencialmente a 99, casi cuatro veces más. ${ }^{24}$ Unos meses más tarde, el 4 de marzo de 1946 se reglamentarán las regulaciones de los No-Do, explicitándose como uno de sus fines la «edición y exhibición de Noticiarios cinematográficos en español, con carácter de exclusividad», siendo compuestos por material fílmico producido en España, pero también aquél «procedente de los Noticiarios extranjeras, según los pactos que con ellos se establezcan o de las noticias que pueda obtener por medio de sus corresponsales».25 Una muestra de los tratados y de las relaciones entre ambos países es que el 21 de octubre de 1946 empieza a aparecer una sección titulada

\footnotetext{
22 Mercedes Rodríguez Sánchez, «La Segunda Guerra Mundial en el NO-DO (1943-1945)».

${ }_{23}$ Cada producción semanal del No-Do contaba con dos ediciones, caracterizadas como «A» $\mathrm{y}$ « $\mathrm{B}$ ». La primera versión «B» fue en el número 15 del 12 de abril de 1943, siendo constante desde el número 20 del 17 de mayo de ese mismo año.

${ }^{24}$ Entre 1943 y 1945 hubo 146 ediciones, en tanto que, en los siguientes tres años, entre 1946 y 1948 se proyectaron 166 No-Do.

${ }^{25}$ «Disponiendo la proyección obligatoria y exclusiva del Noticiario Cinematográfico Español y concediendo la exclusividad absoluta de reportajes cinematográficos a la entidad editora del mismo, Noticiario y Documentales Cinematográficos "No-Do"». Boletín Oficial del Estado (España; 22/12/1942): 10444.
} 
«Argentina y España», que aparecerá en veintitrés ocasiones hasta el 25 de junio de $1973 .{ }^{26}$

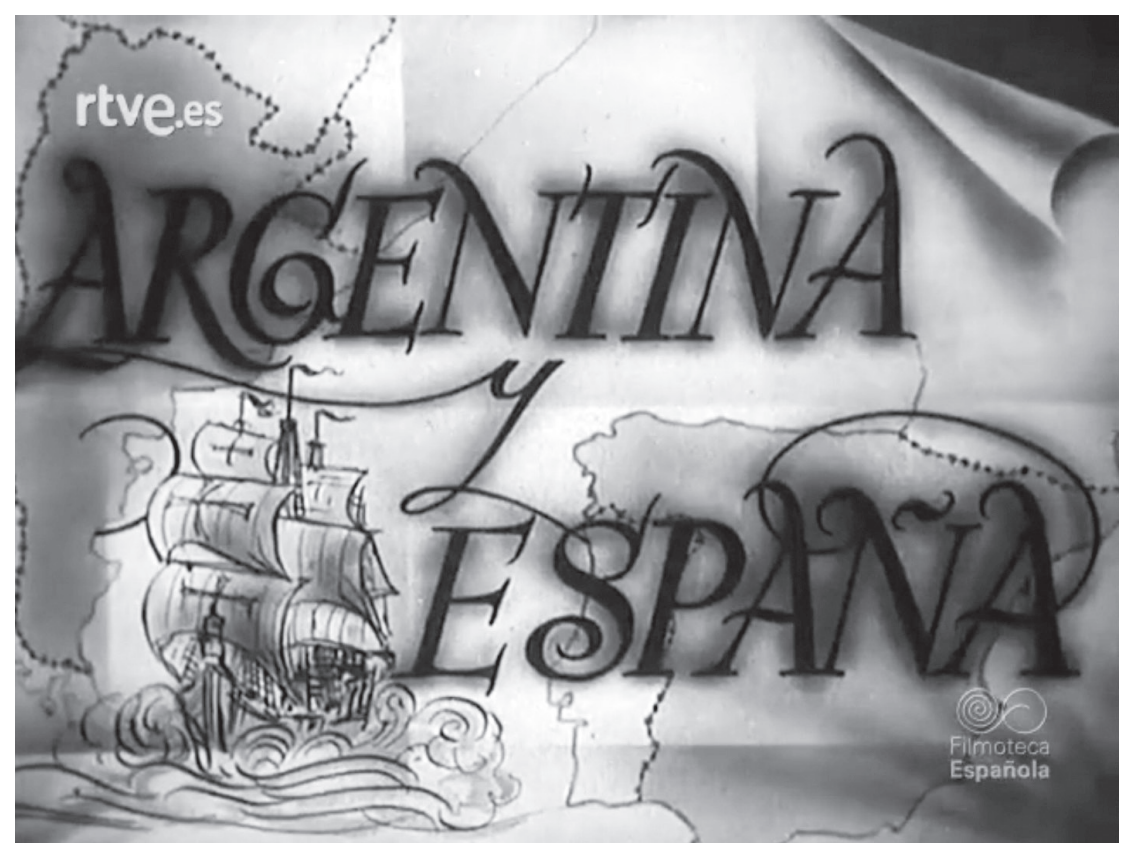

Imagen 2. Intertítulo «Argentina y España» - No-Do n. ${ }^{\circ}$ 231B (02/08/1948).

Además de este crecimiento cuantitativo, también existió un componente cualitativo: Vicente Sánchez-Biosca sostiene que el intercambio con Argentina le permitía al gobierno español desplegar una imagen de desfascistización del régimen, un intercambio que consistió en una suerte de generoso y prolongado "pago informativo a la Argentina de Perón», ${ }^{27}$ y que inclusive trascendería el gobierno peronista una vez derrocado el 21 de septiembre de 1955. Dicho de un modo más directo, «el régimen de Franco emprendió una labor de maquillaje de sus instituciones desde

\footnotetext{
${ }^{26}$ Ejemplo de la relevancia fílmica editorial de este convenio es que existieron otros intertítulos que relacionaban España con otro país, pero ninguno tan recurrente: Portugal aparece con 8 menciones en las placas que anteceden las noticias, Filipinas con 4, Brasil y Norteamérica con 3, Turquía con 2 y Perú, Méjico, Grecia, Alemania, Francia, Costra Rica, Tunes, Paquistán y Estados Unidos con una mención.

27 Vicente Sánchez-Biosca, «La hispanidad en la pantalla del No-Do». En Cine documental en América latina, ed. Paulo Antonio Paranaguá (Madrid: Ediciones Cátedra, 2003): 109-122.
} 
1944, negando cualquier veleidad fascista en el pasado» ${ }^{28}$. La constante presencia de noticias sobre la visita de Eva Perón a España en 1947 resultó clave para que el aparato informativo y de propaganda desarrollara una comunicación no-bélica, demostrada de manera elocuente en el intertítulo del No-Do n. ${ }^{\circ} 232 \mathrm{~A}$ del 16 de junio de 1947, con el que se definía el viaje de la esposa del Presidente argentino: una «mensajera de paz». ${ }^{29}$ Finalmente, entre 1949 y 1955 tuvo una variación relativamente constante, que osciló entre los cinco y once micros fílmicos sobre Argentina por año. ${ }^{30}$

\section{LA MIRADA ESPAÑOLA SOBRE LA EDUCACIÓN ARGENTINA}

Esta investigación comienza de una manera relativamente azarosa cuando, gracias a que en una estadía académica durante 2015 se realizó una visita a la Filmoteca Española en Madrid, procurando ver los discursos visuales y narrativos sobre la cultura física en la prensa cinematográfica española, se encontró parte del material que aquí se presenta y analiza: una serie de imágenes que fueron exhibidas con anterioridad en los Sucesos Argentinos y que se proyectaron posteriormente en el NoDo. En esa búsqueda de imágenes sobre educación del cuerpo en la Filmoteca Española, localizando micros fílmicos mayoritariamente españoles sobre eventos deportivos, muestras de gimnasia, la enseñanza de la danza especialmente para las mujeres, clases escolares de Educación

\footnotetext{
${ }_{28}$ Rafael Tranche y Vicente Sánchez-Biosca, No-Do. El tiempo y la memoria (Madrid: Ediciones Cátedra, 2006), 410.

${ }^{29}$ La visita de Eva «Evita» Duarte de Perón a España en 1947 como Primera Dama Argentina implicó 14 micros fílmicos en el No-Do, lo que significa una presencia constante entre junio y julio. Al respecto se recomienda leer Emeterio Díez Puertas, «Evita en España: máscaras de una Primera Dama», Comunicación y Sociedad, 27 (3), (2014): 107-126 y Beatriz Martínez del Fresno, "Cantos y bailes para María Eva Duarte de Perón. El viaje a España de 1947 y la puesta en escena de la hispanidad», Resonancia: revista de investigación musical, 21 (41), (2017): 87-119. En Perón, sinfonía de un sentimiento el cineasta Leonardo Favio (1999) desarrolla una particular mirada estéticopolítica sobre la visita de Evita a España. Leonardo Favio, Perón, sinfonía de un sentimiento. Argentina: Fundación Confederal/101 SRL (1999): 346 min.

30 Vale la pena mencionar que entre 1943 y 1952 la Dirección del No-Do estaba a cargo de Joaquín Soriano y la Subdirección de Alberto Reig, el Redactor Jefe era Figuerola Ferretti, trabajaban en la Redacción Alfredo Marqueríe y José Manuel Lorenzo Carriba, la Producción estaba en manos de José Darder y de Juan Gómez, el encargado del área deportiva era Matías Prats y los locutores fueron José Hernández Franch e Ignacio Mateos, siendo impresos en los Laboratorios Riera. A partir de 1953 Reig pasó a ocupar la Dirección, José Mateo la Jefatura de un equipo compuesto por Carriba, Prats, Hernández Franch y Dardé (en exteriores). Como locutores se sumaron Matías Prats y José Luis Pécker.
} 
Física, entrenamientos militares mayoritariamente para hombres, entre otros, se hallaron dos materiales que modificaron el curso de la investigación: en las ediciones 16A y 17A del No-Do se muestran imágenes de cultura física de Argentina.

Ello motivó a extender la mirada y agudizar la búsqueda, descubriendo que estos micros fílmicos relevados no fueron los únicos que cruzaron el océano Atlántico de oeste a este. Además, despertó un conjunto de preguntas: ¿por qué se muestran imágenes escolares o educativas argentinas en territorio español? ¿Cómo se dio el tránsito de las cintas de celuloide entre Argentina y España para su proyección? ¿Es el criterio de ahorro en la producción de películas lo que motivó que viajen las imágenes escolares argentinas para ser mostradas como noticias españolas? Además, cabe interrogarse por su contenido: ¿son los mismos planos, montajes y encuadres que se proyectan en Sucesos Argentinos y en NoDo? ¿El sonido que acompaña los fotogramas es idéntico en términos de música de fondo y sobre todo de la narración de los locutores? ¿Cómo titulan los Noticiarios y Documentales españoles las informaciones provenientes de Argentina?

Antes de continuar, cabe definir el criterio de búsqueda de aquello educativo que permitió el proceso de selección del material a analizar. Para ello se utilizó como base el «Registro de los reportajes y noticias del No-Do en los que aparece representada la educación (1943-1975)», elaborado bajo la coordinación de Eulàlia Collelldemont Pujadas y equipo, ${ }^{31}$ en el cual se señala como educativo "el desarrollo de la persona y su integración en la sociedad, integrando con ello aquellas noticias que hacen referencia a la infancia y a su educación, así como la formación en la juventud, en personas adultas o en la tercera edad». Dentro de este contexto se tuvieron en consideración diversas campañas propagandísticas para la formación de modelos correctos de comportamientos y diversos espacios de educación formal y no formal. Según este Registro, existen nueve referencias a la Argentina en los No-Do que tematizan sobre la educación, de las cuales siete se producen en el período que aquí se estudia entre 1943 y 1956.

\footnotetext{
31 Para una descripción y análisis de este registro, véase Eulália Collelldemont Pujadas, Núria Padrós-Tuneu y Pilar Prat Viñolas, «El registro de documentales y noticiarios, una oportunidad para incrementar la documentación del patrimonio histórico educativo», Revista Iberoamericana Patrimonio Histórico-Educativo, 5 (2019): 1-18.
} 
Ahora bien, para esta investigación se resignificaron los criterios de este Registro, lo cual amplió la base de datos a veintiún micros fílmicos con referencias cruzadas a la educación y a la Argentina. Según los criterios de este análisis, se interpretan como imágenes educativas aquellas que aluden a procesos de escolarización con seres humanos, que pueden haber sido producidos tanto dentro como fuera de las escuelas pero que pretenden transmitir sentidos sobre la formación en su más amplio concepto. En otras palabras, retomando la hipótesis inicial de que los noticieros cinematográficos funcionaron como dispositivos pedagógicos, se estableció un recorte de aquellas imágenes que eduquen mediante la mostración, pero también que muestren algún tipo de sentido distintivamente educativo. Dentro de este universo se seleccionaron los fotogramas que refieren específicamente a la Argentina, sea porque son actividades que se desarrollaron en ese país o porque ciudadanos argentinos participaron de alguna noticia.

Tabla 1. Ediciones de No-Do que refieren a Argentina y a la educación+Argentina entre 1943 y 1955 [Elaboración propia]

\begin{tabular}{|c|c|c|}
\hline Año & $\begin{array}{c}\text { No-Dos que refieren a } \\
\text { Argentina }\end{array}$ & $\begin{array}{c}\text { No-Dos que refieren a la } \\
\text { educación+Argentina }\end{array}$ \\
\hline 1943 & 17 & 4 \\
\hline 1944 & 7 & 1 \\
\hline 1945 & 1 & 2 \\
\hline 1946 & 12 & 7 \\
\hline 1947 & 58 & 4 \\
\hline 1948 & 29 & 1 \\
\hline 1949 & 7 & 0 \\
\hline 1950 & 11 & 0 \\
\hline 1951 & 6 & 0 \\
\hline 1952 & 8 & 1 \\
\hline 1953 & 10 & 1 \\
\hline 1954 & 7 & 21 \\
\hline 1955 & 5 & \\
\hline Total & 178 & \\
\hline
\end{tabular}

* Hasta el derrocamiento de Perón, el 21 de septiembre de 1955. 
Como puede observarse en la tabla n. ${ }^{\circ} 1$, se proyectaron un total de 178 noticias sobre Argentina en las 663 ediciones del No-Do desde 1943 hasta el derrocamiento de Perón en septiembre de 1955 (unas 1306 si se cuentan la A y B). De este conjunto de películas aparecen 21 micros fílmicos sobre la enseñanza y el entrenamiento deportivo, campeonatos escolares, muestras gimnásticas, el adiestramiento y tareas militares o policiales, visitas protocolares políticas a establecimientos educativos, entre otras. A continuación se presenta otra tabla (n. $\left.{ }^{\circ} 2\right)$ en la que se explicitan aquellas noticias proyectadas en España a través del No-Do sobre cuestiones referidas a proceso de escolarización. Resulta preciso hacer una serie de explicitaciones acerca de este cuadro:

- se consigna la fecha de emisión de los fotogramas, pero ello no implica cuándo fueron registrados por la cámara. Esto es, la fecha en que se produjo el evento filmado puede haber sido con meses de antelación, teniendo en cuenta el tiempo de traslado de las imágenes a través del océano Atlántico;

- el título representa el intertítulo que antecedía la noticia, y es relevante porque da cuenta de un criterio editorial por parte de No-Do que en muchos casos hacía encajar el micro fílmico en formatos preestablecidos. De allí que se haya elaborado una columna de categoría de análisis según los criterios de esta investigación;

- la columna «Descripción» es una transcripción de aquello que reseña el programa de mano que acompañaba cada No-Do;

- la duración permite ver la importancia de algunas de las noticias, si eran centrales o se trataba de lo que se conoce comúnmente como notas de color. También es posible hacer una interpretación de la relevancia según el lugar que ocupaban en el noticiario semanal, a partir de reconocer que generalmente los micros fílmicos ligados a eventos políticos oficiales se encuentran al comienzo, en tanto que las noticias menores, como la moda, los deportes o las noticias internacionales se transmitieron más cerca del fina;

- la columna sobre quienes produjeron las imágenes es una interpretación basada en el origen de las mismas (si eran filmadas en Argentina o en España), cruzada con relevamientos de material proyectado en los Sucesos Argentinos. 


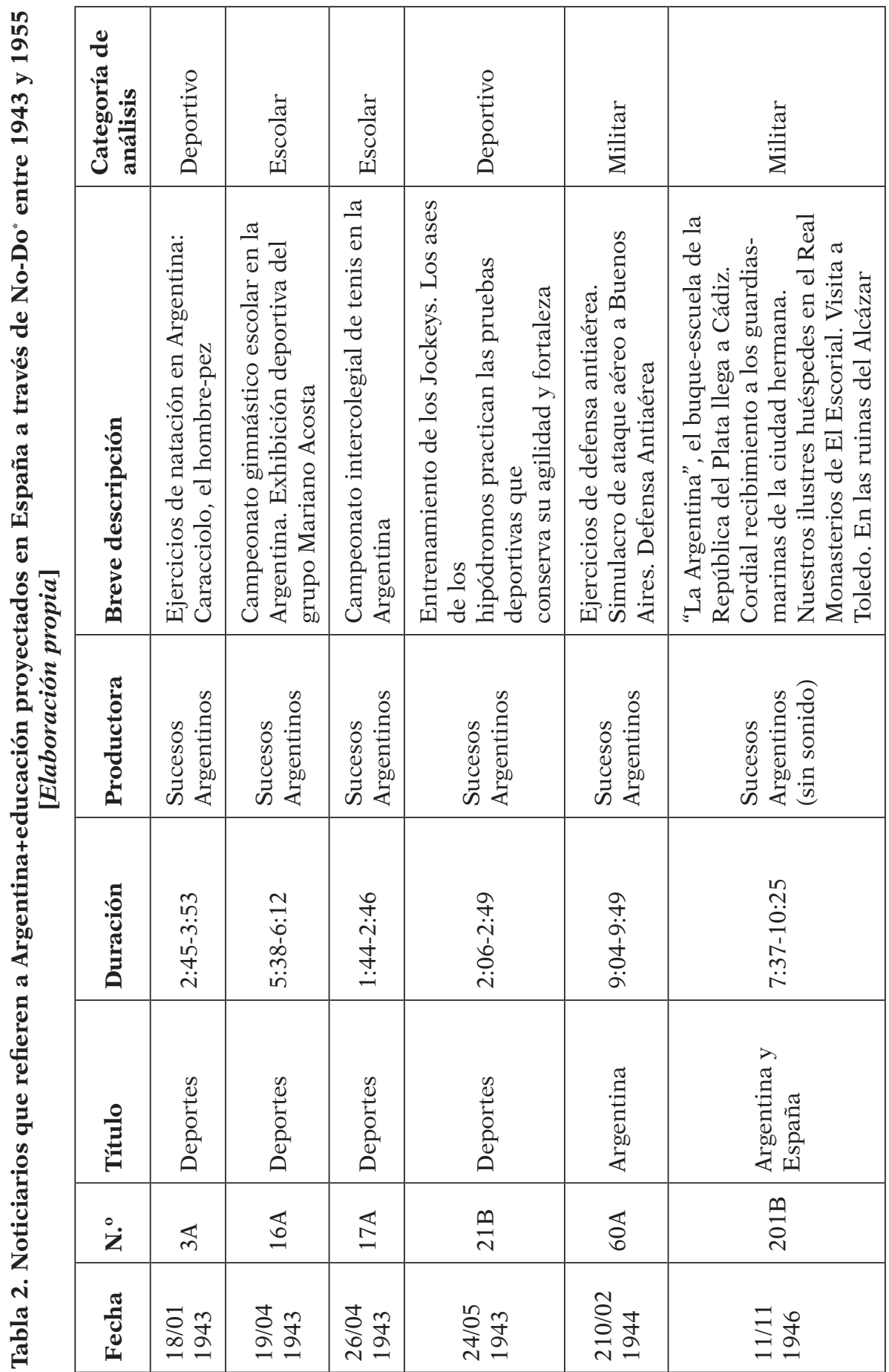




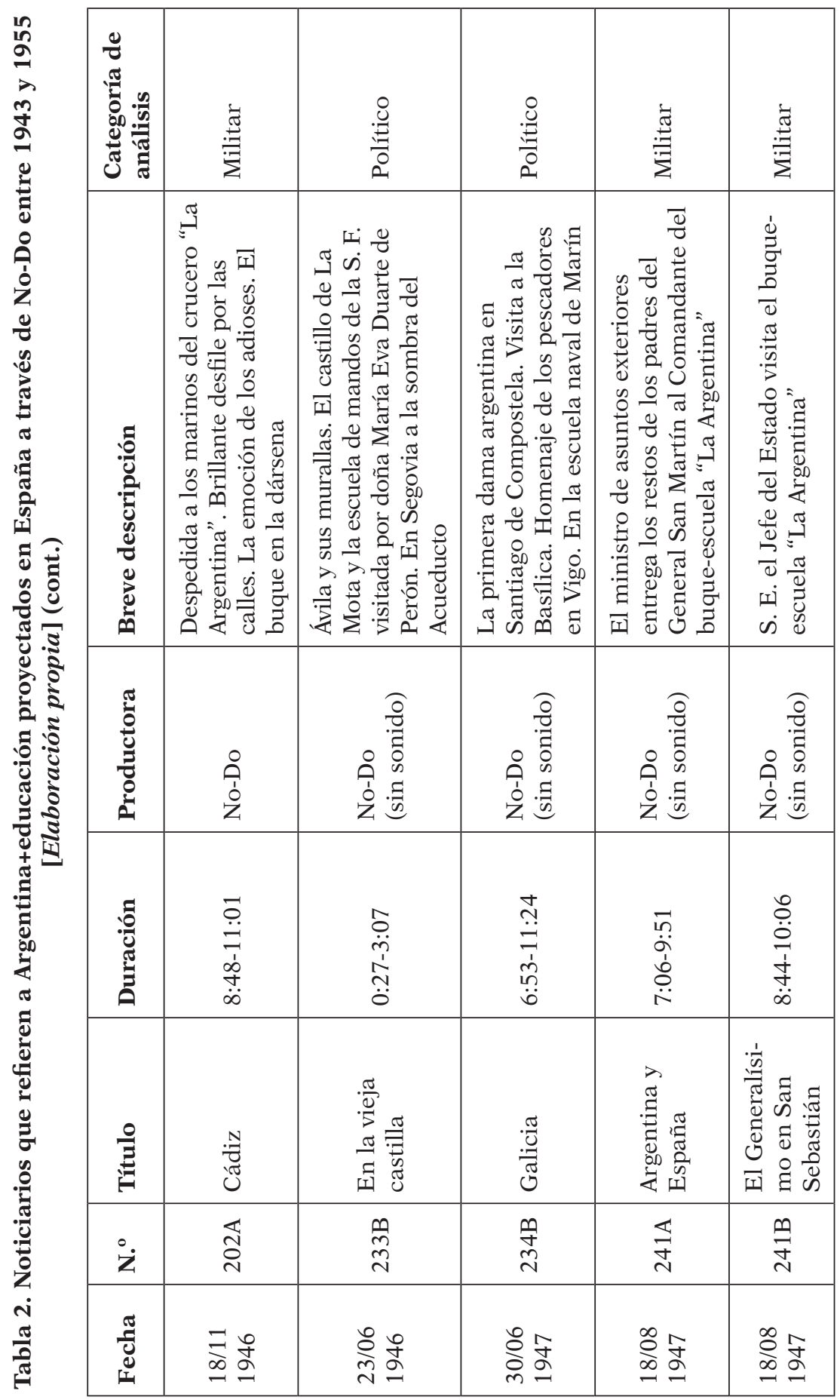


- Eduardo Lautaro Galak

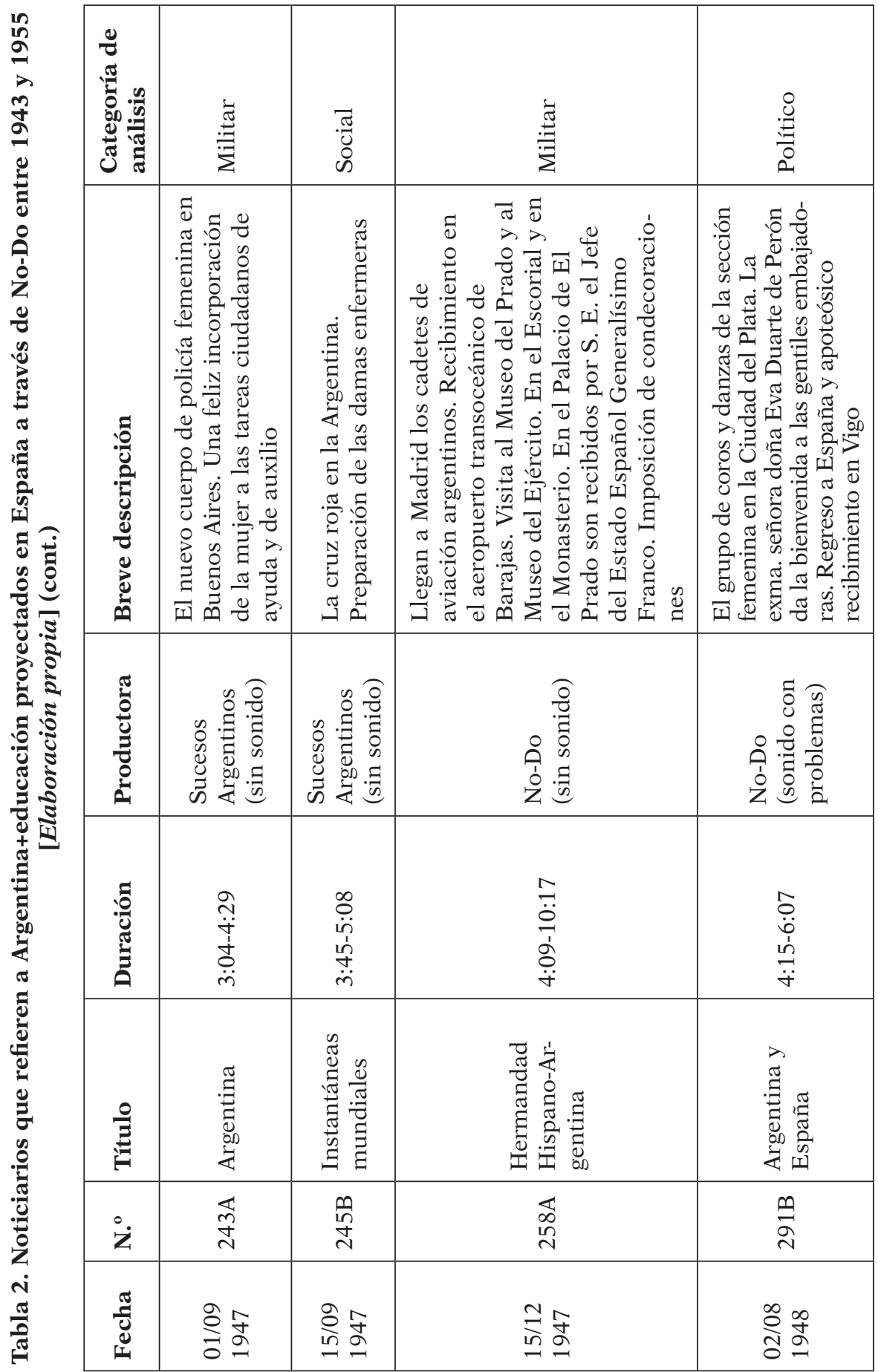




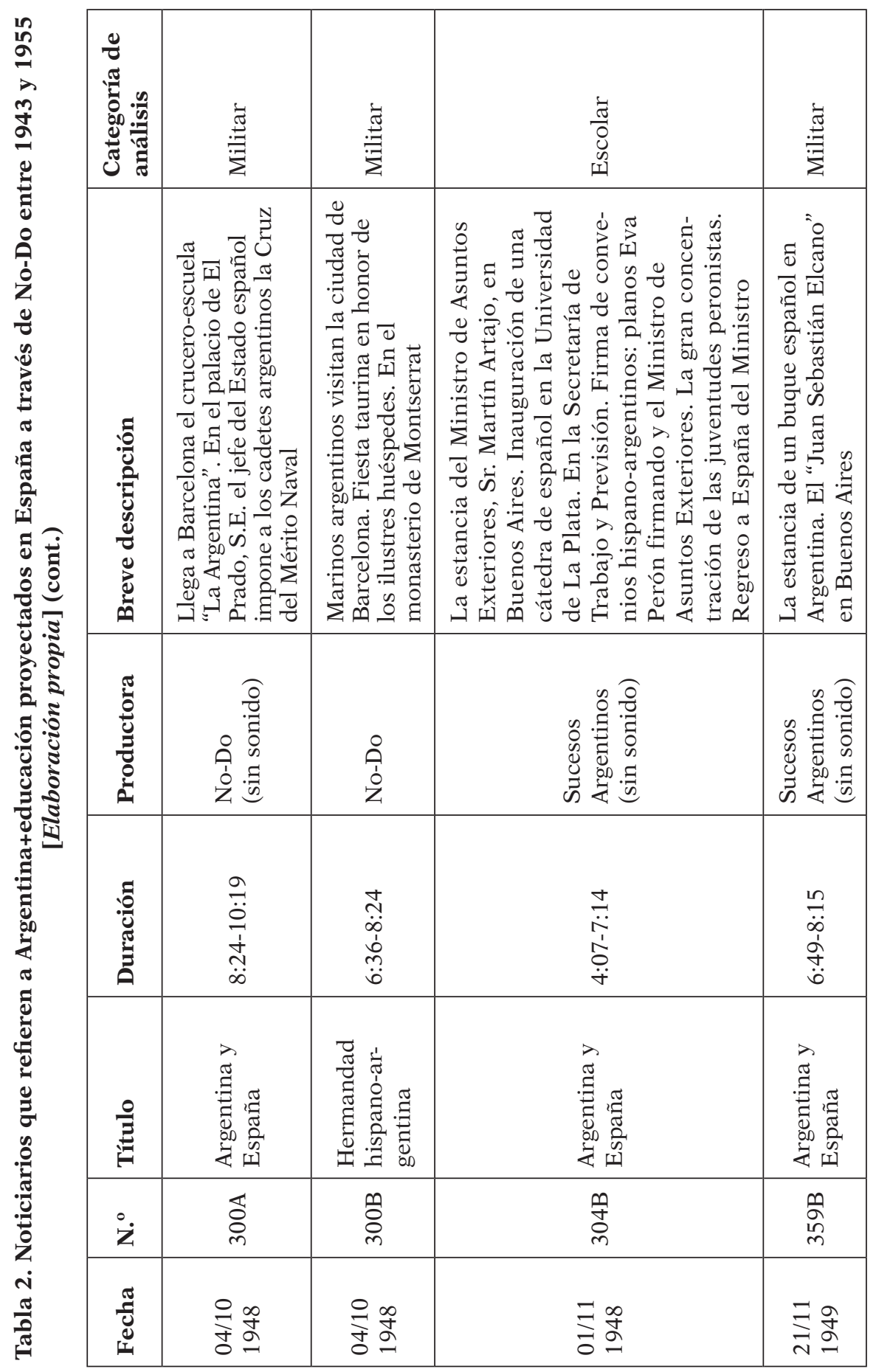




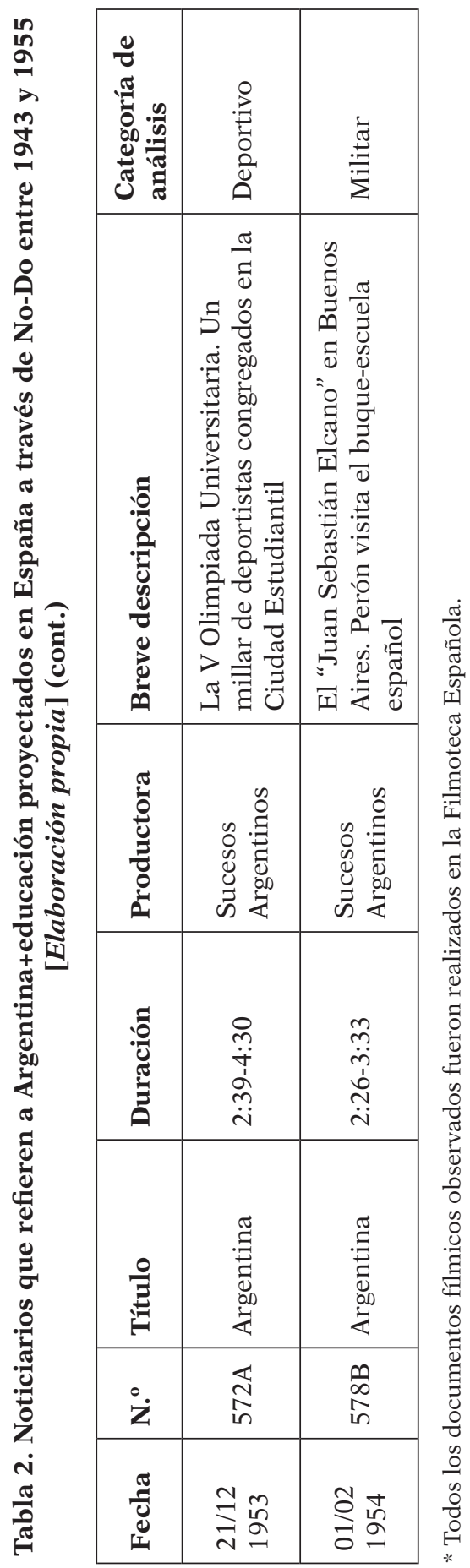


Según las categorías de análisis construidas en base al motivo central de la noticia, existieron once micros fílmicos sobre cuestiones militares o policiales que relacionan lo educativo con la Argentina, tres sobre prácticas o entrenamientos deportivos, tres sobre eventos políticos, tres sobre actividades escolares o universitarias y uno sobre asuntos sociales o culturales. Una primera mirada evidencia que sobresalen las imágenes educativas fuera de ámbitos escolares, como la regulación del tiempo libre (especialmente el entrenamiento deportivo) y del trabajo (mayoritariamente militar o policial), antes que fotogramas de escuelas, colegios, institutos, centros de formación profesional, centros de estudios superiores, universidades, entre otros. Inclusive el criterio de extensión de los micros fílmicos y el lugar que ocuparon en el noticiario semanal abona esta premisa: las noticias que se transmitieron en los espacios centrales fueron aquellas referidas a asuntos militares y políticos. Precisamente esos asuntos son los únicos producidos por el organismo oficial español Noticiarios y Documentales (nueve en total), en tanto las imágenes realizadas por los Sucesos Argentinos fueron más diversas: abarcaron lo deportivo, lo escolar, lo social, lo militar/policial y lo político (doce en total). Con lo cual puede interpretarse un criterio editorial de qué fotogramas que atravesaron el Atlántico valía la pena proyectar.

Respecto del género y las sexualidades, más allá de que no sea notorio un desequilibrio entre las noticias centradas en lo masculino y en lo femenino, sí es posible observar una especificación cuando se trata de cuestiones atinentes a las mujeres. En otras palabras, no hay explicitaciones de que una actividad u objeto sea para los hombres, pero sí existió una particularización sobre lo femenino. Micros fílmicos en los que se describen actividades de «la mujer/ esposa de» -en referencia a la Primera dama argentina, Eva Duarte de Perón (233B; 234B; 291B), o la compañera del nadador Caracciolo sirviéndole a su marido (3A)-, sobre cuestiones profesionales -como la incorporación al cuerpo policial (243B) o el trabajo de enfermeras (245B)- o deportivas -como campeonatos escolares que muestran competencias de jóvenes tenistas (17A) exhiben de manera elocuente el rol social de la mujer argentina a mediados de siglo XX, entre el tradicional orden patriarcal heteronormativo que la ubica como sinónimo de madre/esposa y el renovado espíritu feminista marcado por la ola sufragista, que reivindica el derecho ciudadano pleno al voto y que la significa como miembro activo de la sociedad en tanto trabajadora. ${ }^{32}$

\footnotetext{
32 Para profundizar sobre un análisis de los discursos sobre lo femenino durante la década peronista,
} especialmente centrado en el derecho a voto y en la figura de Eva Perón, se recomienda la lectura de 
En cuanto a la cuestión etaria, resulta manifiesto que todas las noticias sobre lo social (245B), lo deportivo (3A; 21B; 572A) y lo escolar (16A; 17A; 304B) estén centradas en un discurso sobre y para los jóvenes. A su vez, a este listado cabe agregar las exhibiciones políticas de jóvenes bailando o cantando (291B), la profesionalización de las juventudes (243A) y sobre todo los intercambios militares educativos entre ambos países (201B; 202A; 241A; 241B; 300A; 300B; 359B; 378B). Con todo ello puede interpretarse que cuatro de cada cinco noticias que interrelacionan educación y Argentina tuvieron como su objeto de mensaje la formación de las subjetividades y los cuerpos de las juventudes, conjunto del cual se seleccionan tres noticias para su análisis debido a su representatividad.

\section{Las imágenes: cultura física y juventud}

El 4 de enero de 1943 apareció en las pantallas de los cines españoles el primer No-Do, en el cual, tras un intertítulo que decía «Argentina», se hace referencia a la misión comercial hispánica del buque Cabo de Hornos en aquel país. Apenas dos semanas más tarde, el 18 de enero, se proyectaban en la tercera edición las primeras imágenes sobre educación argentina: un concurso de natación para jóvenes organizado por «el Departamento de Cultura Física de la Argentina». Según la crónica del locutor hispánico, «los aspirantes a campeones fueron adiestrados por Ernesto Caracciolo, el supercampeón que llegó a poseer 18 marcas de río, mar y piscina». Luego se produce una modificación estética de las imágenes: con un cambio repentino de musicalización de fondo, que pasa al típico movimiento instrumental que acompaña imágenes de travesuras o bromas, comienza un acto filmado que transforma el registro fílmico de noticia al de nota de color. Acto seguido, se lo muestra a Caracciolo desarrollando piruetas subacuáticas: como parte de «sus habilidades de hombre pez», mientras hace apnea debajo del agua, realiza la mímica de dormir, de despertarse, de tomar algo cuando «una sirena atiende el pedido del señor», vestida con un delantal que asemeja al de sirvienta, para luego hacer monerías frente a la cámara, "después se entrega a la lectura y también hace un poco de gimnasia» dando vueltas

Susana Bianchi, «Las mujeres en el peronismo (Argentina 1945-1955)», en Historia de las mujeres en Occidente, Vol. 5, ed. Françoise Thébaud (Madrid: Taurus, 1993), 697-708. 
en círculos. La nota cierra con Caracciolo encima de un juguete inflable que imita a un caballo, mientras el locutor señala que «finalmente, nos muestra como la equitación puede ser un deporte acuático».33

El 19 de abril de ese mismo año, en la sección «Deportes», aparece la noticia que según el programa de mano que se adjuntaba a cada No-Do se trataba de un "Campeonato gimnástico escolar en la Argentina». El locutor español comienza por señalar que se trata de una actividad desarrollada por el «Departamento de Educación Física de la Argentina», el cual organiza las pruebas eliminatorias para el «gran campeonato gimnástico intercolegial». De fondo, una música alegre acompaña las imágenes de jóvenes varones escolares marchando con la bandera argentina. Luego, todos vestidos con uniformes blancos, realizan en una cancha de fútbol una exhibición de gimnástica calisténica, en filas e hileras, haciendo todos, lo mismo, al mismo tiempo: se trata de un grupo de estudiantes del tradicional colegio porteño Mariano Acosta, «uno de los más disciplinados conjuntos deportivos» según el cronista, que hace las actividades con público en las gradas, el cual, para finalizar, forma con pancartas celestes y blancas la bandera argentina. Más allá de la puesta en escena de una juventud de cuerpos fuertes acompañada de retóricas patrióticas chauvinistas, lo interesante de estas imágenes es que se dispone de su origen: se trata de fotogramas que pertenecieron a la edición 213 de los Sucesos Argentinos, exhibida en las salas al otro lado del océano el 22 de septiembre de 1942, tras el intertítulo «La juventud argentina perfecciona su Educación Física». Es decir, siete meses más tarde, se mostraba como novedad en España, como noticia, un campeonato escolar argentino. Lamentablemente no quedan registros del sonido que acompañaba a las imágenes de Sucesos Argentinos, pero sí puede asegurarse que se trata del mismo encuadre, montaje y planos. ${ }^{34}$

\footnotetext{
33 «Ejercicios de natación en Argentina: Caracciolo, el hombre-pez», No-Do, 3A, 18/01/1943. Entre enero y febrero de 1968 se editó en el No-Do una sección que se titulaba «Hace veinticinco años», que volvía a poner en pantalla noticias viejas, conmemorando los inicios de este noticiero cinematográfico. Esta nota sobre natación en Argentina fue proyectada en la edición 1305B, el 8 de enero de 1968, aunque con algunas diferencias: si bien eran las mismas imágenes, la crónica está centrada solo en Caracciolo, y los chistes no son los mismos, con el locutor diciendo que el hombre pez tomaba un vaso de licor "porque, aunque parezca mentira, el hombre está seco», o que subacuáticamente «lee las normas para fabricar un impermeable en 15 días».

34 «Campeonato gimnástico escolar en la Argentina. Exhibición deportiva del grupo Mariano Acosta», No-Do, 16A, 19/04/1943.
} 
En la edición siguiente del No-Do, la 17A del 26 de abril de 1943, aparece otra vez dentro de la sección «Deportes», una noticia que se relaciona con las anteriores, catalogada según el programa de mano como "Campeonato intercolegial de tennis [sic] en la Argentina». El locutor español comienza su crónica por identificar que se trata de un evento «organizado por la Dirección General de Educación Física de la Argentina» y con "participación de todas las representaciones escolares tiene lugar el gran campeonato intercolegial de tenis». Se muestra un partido de dobles femenino en el que triunfa la Escuela Normal n. ${ }^{\circ}$ 6, con mayoría de jóvenes mujeres en el público. Ahí la noticia se torna una nota de color: mientras el narrador dice que «una travesura de la cámara da al partido de tenis inusitada velocidad», se produce una proyección en aceleración, un time-lapse en cámara rápida haciendo de la actividad deportiva un hecho llamativo, gracioso. Inclusive se muestran los camarógrafos, quienes «no pueden captar tanta rapidez», y el público, que «también se vuelve loco».

Con este micro fílmico se cierra una triada de noticias que parece provenir del mismo seno: una entidad oficial argentina dedicada a la educación escolarizada de los cuerpos. Si bien se la refiere de modos diferentes, como «Departamento de Cultura Física» (3A), como «Departamento de Educación Física» (16A) y como «Dirección General de Educación Física»(17A), lo cierto es que no da la impresión de ser el resultado de eventos organizados por un club deportivo, sino por una institución oficial. Por aquellos años funcionaba con un significativo apoyo estatal la Dirección General de Educación Física, creada como dependencia del Ministerio de Justicia e Instrucción Pública el 17 de junio de 1938 y de cuya administración se encargará César Sotero Vázquez. ${ }^{35}$

En otro orden de cosas, estos tres No-Do que proyectaron imágenes que relacionan la Argentina y la educación fueron registrados y producidos por los Sucesos Argentinos. Lamentablemente, rastrear el derrotero de estas imágenes cruzando el Atlántico es prácticamente imposible. Sin embargo, no es menor el señalamiento de este viaje de un país americano

\footnotetext{
35 Eduardo Galak, «Del dicho al hecho (y viceversa). El largo trecho de la construcción del campo de la formación profesional de la Educación Física en Argentina. Legalidades, legitimidades, discursos y prácticas en la institucionalización de su oficio entre finales del siglo XIX y el primer tercio del XX» (Tesis doctoral, Universidad Nacional de La Plata, 2012), 329.
} 
a uno europeo porque, a pesar de las distancias, se mantiene la narrativa oficial sobre los cuerpos, la prescripción de qué hacer y sobre todo para qué, de los modos correctos de hacer y de ser. Queda pensar cómo se produce esta internacionalización de las imágenes, el criterio editorial para su selección, tanto en el envío como en la recepción, en la elección de las palabras que acompañan la narración. En síntesis, queda pensar en las distancias materiales, geográficas, pero también en las distancias simbólicas, en aquellas políticas y estéticas que hacen de la imagen un potencial artefacto cultural para la construcción de imaginarios.

\section{CONSIDERACIONES FINALES}

¿Cómo se produjo la trasnacionalización de las imágenes y de los modos de narrar prácticas corporales educadas? ¿Puede identificarse un diálogo en las formas de exhibir los cuerpos jóvenes moviéndose, maneras particulares de cada contexto, o se trata de modos universales de mostrarlos?

Las referencias en noticieros españoles a la relación entre Argentina con su «madre patria», la imagen de la carabela de fondo de las palabras «Argentina y España» o el interés por mostrar noticias sobre el «Día de la raza» como conmemoración del desembarco de hispanos en Latinoamérica, son instantáneas que reflejan que la colonización de mediados del siglo XX porta como característica apelar a la tradición como valor. Empero, esta dependencia histórica económica, cultural y política no se condice enteramente con los mensajes transmitidos en los celuloides provenientes de Argentina en el No-Do, especialmente aquellos que tuvieron como parte central de su mensaje sentidos educativos: lo argentino es exhibido con legitimidad propia. A su vez, resulta interesante la puesta en pantalla de una hermandad hispano-argentina -que inclusive se explicitaba en los intertítulos que antecedían los micros de prensa filmada (como en las ediciones 258A y 300B)-, la cual se mostraba atravesada por sentidos patrióticos que reivindicaban con grandilocuencia las obras de gobierno de Perón y de Franco a ambos márgenes del océano Atlántico. Esto es, los discursos del cine documental informativo español sobre Argentina conjugan universalidades con particularidades, internacionalización y chauvinismo, cuyo equilibrio está centrado en un pueblo (ibérico o argentino) pretendidamente homogéneo dirigido por líderes patriarcales. 
El hecho de que el cine documental informativo haya sido desarrollado más tempranamente en Argentina, sumado a la crisis económico-social que se vivía en España a la salida de la Segunda Guerra Mundial y a las vicisitudes del mercado cinematográfico internacional, contribuyeron a que las imágenes argentinas encuentren un lugar en donde ser proyectadas fuera de sus fronteras nacionales. Si bien esta diferenciación, parece haber una clave de lectura común entre los fotogramas producidos por los Sucesos Argentinos y por el No-Do: una relativa concentración del discurso en la cultura física como recurso y en las juventudes como su principal destinatario. Si en el género documental informativo la acción del Estado es mostrada como la acción sobre los cuerpos, ${ }^{36}$ entonces, para el caso de estos fotogramas españoles proyectados en los inicios del No-Do, el ideario sobre lo educativo argentino es que el cuerpo correcto es aquél que es sinónimo de vigoroso, ágil, fuerte, útil, disciplinado y sobre todo patriótico.

Vale la pena señalar en este registro la tensión irresuelta entre lo particular y lo universal que reflejan las imágenes: son cuerpos mostrados como representativos de la patria -argentina o española-, pero utilizando retóricas fílmicas genéricas, como las actividades físicas masivas o el impersonalismo de quien ejecuta el movimiento, algo que es relativamente recurrente también para miradas supuestamente antagónicas, como la soviética, la estadounidense o para el nazismo. En otras palabras, pareciera ser que los fotogramas de los cuerpos en movimiento podrían haberse intercambiado entre países Aliados, del Eje o de la Tercera Posición, aunque reivindiquen chauvinismos diferentes: con sus profundos matices, todos ellos pregonaban una acción gubernamental sobre los cuerpos, reivindicando como retórica la formación de cuerpos sanos, bellos y jóvenes. Empero, las diferencias de cada contexto no están en los físicos exhibidos en pantalla, sino en la voz del locutor, que acentúa narrativamente aquello que se quiere significar con las imágenes, desplegando así un discurso audiovisual que se proyecta como dispositivo pedagógico.

A su vez, como parte del uso de técnicas cinematográficas como la cámara rápida o subacuática, es posible interpretar que las técnicas corporales son también liberadoras, potencialmente abiertas al divertimento, al

36 Galak, «Educar (con) la mirada», 55-74. 
deseo, a lo contingente, a la subjetividad, a la sensibilidad. Las imágenes muestran una narración cronológica lineal, simplificada, que a la vez simplifica las técnicas que desarrollan los cuerpos en movimiento, haciendo confundir lo que se hace con lo que hay que hacer: su masificación masifica también la idea de que todos podemos -pero sobre todo debemos- hacer lo que se exhibe. El espacio fílmico se muestra como conocido, valiéndose del montaje para proyectar fotogramas que sean percibidos como populares, propios, representativos de la españolidad o de la argentinidad-aunque hayan sido producidos en la otra orilla del océano Atlántico-. Para ello se utiliza especialmente como estrategia cinematográfica el registro de las actividades mediante una frontalidad modificada que incluya al observador y mantenga la ilusión de que es parte de ese colectivo ficcional que se funde entre la imagen documental y el espectador. ${ }^{37}$

El conjunto de tres noticieros cinematográficos analizados pone en el centro de la escena una educación de los cuerpos que tienen como eje de su discurso a las juventudes. Ahora bien, es posible observar que ello no se reduce a mostrar fotogramas de jóvenes haciendo alguna práctica corporal, ni a procurar interpelar a un potencial público espectador parte de ese grupo etario, sino más bien a la pretensión política y estética de que funcione como un dispositivo discursivo: la retórica oficial presupone un pueblo joven, sinónimo de vigorosidad, pero también de inexperiencia. A la vez, esto supone un pueblo joven espectador, en tanto, como señala Jacques Rancière, ${ }^{38}$ expectante, pasivo. De allí que no sea casual la fuerte inversión simbólica y material por parte de gobiernos estatales por el uso de los recursos audiovisuales como dispositivos de transmisión de mensajes totalizadores que ubican al líder (Franco o Perón) como padre de las masas. El nacimiento del No-Do, así como el intercambio de noticias filmadas a través del Atlántico, son muestra del tránsito de celuloides para mostrar imágenes que construyan imaginarios sobre las juventudes y los cuerpos argentinos y españoles.

\footnotetext{
37 La técnica de la proyección de imágenes mediante una frontalidad modificada se distingue de la frontalidad total, que implicaría dirigirse ante la cámara de frente, hablándole mientras se la mira, lo cual rompe la ilusión ficcional que el cine propone, inclusive el género documental informativo.

38 Jacques Rancière, El espectador emancipado (Buenos Aires: Manantial, 2010).
} 


\section{Nota sobre el autor}

Eduardo Galak es Profesor en Educación Física (2006), Magíster en Educación Corporal (2010) y Doctor en Ciencias Sociales por la Universidad Nacional de La Plata (2012), con post-doctorado en Educação, Conhecimento e Integração Social (UFMG-Brasil). En la actualidad es Investigador Adjunto del CONICET (Argentina). Ejerce la docencia actuando en grado y posgrados. Es director del proyecto de investigación Procesos de democratización en la formación de los cuerpos y las sensibilidades en la educación estética de la Argentina de la segunda mitad del siglo XX (UNLP-H890) y coordina el Colectivo de Estudios Políticas, Educación y Cuerpo (IdIHCS). En la actualidad es director de la revista Anuario. Historia de la Educación y editor de la revista Educación Física \& Ciencia.

Es autor de los libros Educar los cuerpos al servicio de la política. Cultura física, higienismo, raza y eugenesia en Argentina y Brasil (2016) y Políticas de la imagen y de la imaginación en el peronismo. La radioenseñanza y la cinematografía escolar como dispositivos pedagógicos para una Nueva Argentina (2020). Además, es compilador de Cuerpo y Educación Física. Perspectivas latinoamericanas para pensar la educación de los cuerpos (2013), Cuerpo, Educación, Política: tensiones epistémicas, históricas y prácticas (2015), Sentidos y prácticas sobre la educación y los usos del cuerpo: intercambios académicos entre Argentina, Brasil, Colombia y Uruguay (2019), Le pieghe del corpo (2019) y Por uma epistemologia da educação dos corpos e da educação física (2020).

Es autor de diversos artículos y capítulos de libro en los que trabaja la relación entre educación del cuerpo y (re)producción política, principalmente a través de analizar genealógicamente discursos referidos a la formación profesional, a la estética, al cine, al cientificismo, a la salud e higiene públicas y al mejoramiento de la raza.

\section{REFERENCIAS}

Álvarez Macías, Nuria. «Cine y educación en la España de las primeras décadas del siglo XX. Tres concepciones del cine educativo». Tarbiya, Revista de Investigación e Innovación Educativa 31 (2002): 39-66. 
Argentina. «Fomento a la producción de noticiarios en Argentina». Boletín Oficial de la República Argentina, Decreto Nacional n. ${ }^{\circ}$ 18.405, publicado el 13 de enero de 1944 (1943).

Benjamin, Walter. La obra de arte en la era de su reproductibilidad técnica y otros textos. Buenos Aires: Godot, 2012.

Bianchi, Susana. «Las mujeres en el peronismo (Argentina 1945-1955)». En Historia de las mujeres en Occidente, Vol. 5, editado por Thébaud, Françoise, 697-708. Madrid: Taurus, 1993.

Bourdieu, Pierre. Sobre el Estado. Buenos Aires: Anagrama, 2014.

Cine Argentino. "Sucesos Argentinos. Un exponente del periodismo», Director Propietario Antonio Ángel Díaz, n. ${ }^{\circ}$ 17, 01/09/1938.

Collelldemont Pujadas, Eulàlia y Casanovas Prat, Josep. «Los documentales y noticiarios como texto de apertura para pensar la educación estético-política». Historia y Memoria de la Educación 5. (2017): 467-487.

Collelldemont Pujadas, Eulàlia, Padrós-Tuneu, Núria y Prat Viñolas, Pilar. «El registro de documentales y noticiarios, una oportunidad para incrementar la documentación del patrimonio histórico educativo». Revista Iberoamericana Patrimonio Histórico-Educativo 5. (2019): 1-18.

Collelldemont Pujadas, Eulàlia (coord.). Registro de los reportajes y noticias del NO-DO en los que aparece representada la educación (1940-1975), Vic, MUVIP, 2019. Disponible en: https://www.uvic.cat/sites/default/files/registro_reportajes_y_noticias.pdf. Acceso: 22/01/2020.

Díez Puertas, Emeterio. «Las negociaciones para el acuerdo cinematográfico de 1948 entre Argentina y España (1939-1948)». Secuencias 35. (2012): 59-83.

Díez Puertas, Emeterio. «Evita en España: máscaras de una Primera Dama». Comunicación y Sociedad 27, n. 3 (2014): 107- 126.

Díez Puertas, Emeterio. Cine español y geopolítica fascista: España y sus relaciones cinematográficas con la Argentina (1939-1943). Madrid: Síntesis, 2019.

España. «Disponiendo la proyección obligatoria y exclusiva del Noticiario Cinematográfico Español y concediendo la exclusividad absoluta de reportajes cinematográficos a la entidad editora del mismo, Noticiario y Documentales Cinematográficos "No-Do"». Boletín Oficial del Estado (22/12/1942): 10444.

España. «Orden de 25 de enero de 1946 Por la que se autoriza la aplicación del régimen de suspensión de pago de derechos establecido por la Ley de 19 de julio de 1944 a las noticias cinematográficas extranjeras que se importen con destino a "Noticiarios y Documentales NO-DO" ". Boletín Oficial del Estado (30/01/1946a): 827.

España. «Decreto de 22 de febrero de 1946 por el que se regula el régimen jurídico-económico de Noticiarios y Documentales Cinematográficos (NODO)», Boletín Oficial del Estado. (04/03/1946b): 1697-1698. 
Favio, Leonardo. Perón, sinfonía de un sentimiento. Argentina: Fundación Confederal/101 SRL (1999): $346 \mathrm{~min}$.

Galak, Eduardo. "Del dicho al hecho (y viceversa). El largo trecho de la construcción del campo de la formación profesional de la Educación Física en Argentina. Legalidades, legitimidades, discursos y prácticas en la institucionalización de su oficio entre finales del siglo XIX y el primer tercio del XX». PhD diss., Universidad Nacional de La Plata, 2012.

Galak, Eduardo. «Educar (con) la mirada. Discursos políticos y sentidos estéticos sobre la cultura física en noticieros cinematográficos». En Gregorio Weinberg: escritos en su honor, editado por Gabriela Ossenbach Sauter, 5574. Buenos Aires: CLACSO, 2017.

Galak, Eduardo. "Hacia una estética peronista: educación del cuerpo y formación de subjetividades a través del noticiero cinematográfico "Sucesos Argentinos” (1946-1955)». En La educación de las sensibilidades en la Argentina moderna. Estudios sobre estética escolar, editado por Pablo Pineau, María Silvia Serra y Myriam Southwell, 211-225. Buenos Aires: Biblos, 2018.

Kriger, Clara «La presencia del estado en el cine del primer peronismo». PhD diss., Universidad de Buenos Aires, 2006.

Kriger, Clara. «El noticiero Sucesos Argentinos». Historiapolítica.com, 2007. Disponible en http://historiapolitica.com/datos/biblioteca/kriger.pdf. Acceso: 23 ene. 2020.

Kriger, Clara. Cine y peronismo: el Estado en escena. Buenos Aires: Siglo XXI, 2009.

Luchetti, María Florencia. «¿Qué sucedió en la semana, eh? El noticiario cinematográfico en Argentina. Aportes para la construcción de un objeto». Tesis de Maestría, Universidad de Buenos Aires, 2011.

Luchetti, María Florencia. «El noticiario cinematográfico en Argentina. Un estado de la cuestión». Aniki 3, n. ${ }^{\circ} 2$ (2016): 303-333. doi:10.14591/aniki. v3n2.224

Marrone, Irene. Imágenes del mundo histórico. Identidades y representaciones en el noticiero y el documental en el cine mudo argentino. Buenos Aires: Biblos, 2003.

Martínez, Josefina. "La incidencia de la Segunda Guerra Mundial en el comercio de películas entre España y Argentina. La búsqueda de un acuerdo imposible». Bicentenario. Revista de Historia de Chile y América 7, n. ${ }^{\circ} 2$ (2008): 35-64.

Martínez, Josefina. «La intimidad latina. El intercambio de películas entre Argentina y España durante el primer gobierno de Perón (1946-1955)». Bicentenario. Revista de Historia de Chile y América 8, n. ${ }^{\circ} 2$ (2009): 63-96.

Martínez del Fresno, Beatriz. «Cantos y bailes para María Eva Duarte de Perón. El viaje a España de 1947 y la puesta en escena de la hispanidad». Resonancia: revista de investigación musical 21, n. ${ }^{\circ} 41$ (2017): 87-119. 
Padrós, Núria; Prat, Pilar y Collelldemont, Eulàlia. «La atención sanitaria infantil como preocupación educativa». Revista Iberoamericana Patrimônio Histórico-Educativo 2, n. 3 (2016): 129-141.

Paranaguá, Paulo Antonio. El cine documental en América Latina. Madrid: Cátedra, 2003.

Rancière, Jacques. El espectador emancipado. Buenos Aires: Manantial, 2010.

Rancière, Jacques. Las distancias del cine. Buenos Aires: Manantial, 2012.

Rancière, Jacques. El reparto de lo sensible: estética y política. Buenos Aires: Prometeo, 2014.

Rein, Raanan. La salvación de una dictadura. Alianza Franco-Perón, 1946-1955. Madrid: Consejo Superior de Investigaciones Científicas, 1995.

Rodríguez Sánchez, Mercedes. "La Segunda Guerra Mundial en el NO-DO (1943-1945)». PhD diss., Universidad Complutense de Madrid, 2016.

Sánchez-Biosca, Vicente. "La hispanidad en la pantalla del No-Do». En Cine documental en América latina, editado por Paulo Antonio Paranaguá. Madrid: Ediciones Cátedra, (2003): 109-122.

Tranche, Rafael y Sánchez-Biosca, Vicente. No-Do. El tiempo y la memoria. Madrid: Ediciones Cátedra, 2006. 